\title{
Rubrivivax benzoatilyticus sp. nov., an aromatic, hydrocarbon-degrading purple betaproteobacterium
}

\author{
Correspondence \\ Ch. V. Ramana \\ r449@sify.com \\ or \\ sasi449@yahoo.ie
}

\author{
Ch. V. Ramana, ${ }^{1}$ Ch. Sasikala, ${ }^{2}$ K. Arunasri, ${ }^{2}$ P. Anil Kumar, ${ }^{2}$ \\ T. N. R. Srinivas, ${ }^{2}$ S. Shivaji, ${ }^{3}$ P. Gupta, ${ }^{3}$ J. Süling ${ }^{4}$ and J. F. Imhoff ${ }^{4}$ \\ ${ }^{1}$ Department of Plant Sciences, School of Life Sciences, University of Hyderabad, \\ PO Central University, Hyderabad 500 046, India \\ ${ }^{2}$ Environmental Microbial Biotechnology Laboratory, Center for Environment, Institute of \\ Science and Technology, J.N.T. University, Kukatpally, Hyderabad 500 072, India \\ ${ }^{3}$ Center for Cellular and Molecular Biology, Uppal Road, Hyderabad 500 007, India \\ ${ }^{4}$ Leibniz-Institut für Meereswissenschaften, IFM-GEOMAR, Marine Mikrobiologie, \\ Düsternbrooker Weg 20, 24105 Kiel, Germany
}

\begin{abstract}
A brown-coloured bacterium was isolated from photoheterotrophic (benzoate) enrichments of flooded paddy soil from Andhra Pradesh, India. On the basis of 16S rRNA gene sequence analysis, strain $\mathrm{JA} 2^{\top}$ was shown to belong to the class Betaproteobacteria, related to Rubrivivax gelatinosus (99\% sequence similarity). Cells of strain $\mathrm{JA} 2^{\top}$ are Gram-negative, motile rods with monopolar single flagella. The strain contained bacteriochlorophyll $a$ and most probably the carotenoids spirilloxanthin and sphaeroidene, but did not have internal membrane structures. Intact cells had absorption maxima at 378, 488, 520, 590, 802 and $884 \mathrm{~nm}$. No growth factors were required. Strain JA2 ${ }^{\top}$ grew on benzoate, 2-aminobenzoate (anthranilate), 4-aminobenzoate, 4-hydroxybenzoate, phthalate, phenylalanine, trans-cinnamate, benzamide, salicylate, cyclohexanone, cyclohexanol and cyclohexane-2-carboxylate as carbon sources and/or electron donors. The DNA $\mathrm{G}+\mathrm{C}$ content was $74.9 \mathrm{~mol} \%$. Based on DNA-DNA hybridization studies, 16S rRNA gene sequence analysis and morphological and physiological characteristics, strain $\mathrm{JA}^{\top}{ }^{\top}$ is different from representatives of other photosynthetic species of the Betaproteobacteria and was recognised as representing a novel species, for which the name Rubrivivax benzoatilyticus sp. nov. is proposed. The type strain is $\mathrm{JA} 2^{\top}\left(=\right.$ ATCC BAA $-35^{\top}=\mathrm{JCM} 13220^{\top}=$ MTCC $\left.7087^{\top}\right)$.
\end{abstract}

A small number of low molecular mass aromatic hydrocarbons support the growth of certain purple non-sulfur bacteria (Sasikala \& Ramana, 1998) as carbon sources and/or electron donors. Frank \& Gaffron (1941) first reported aromatic metabolism in an anoxygenic phototrophic bacterium, Rhodovibrio parvus (now placed in Rhodopseudomonas as Rhodopseudomonas palustris), in which phenylpropionate was transformed to benzoate during phototrophic metabolism. Later, Scher and co-workers (Scher \& Allen, 1960; Scher \& Proctor, 1960) demonstrated growth of Rhodopseudomonas

Abbreviations: BChl a, bacteriochlorophyll a; FT-IR, fourier-transform infrared.

The GenBank/EMBL/DDBJ accession number for the 16S rRNA gene sequence of strain $J A 2^{\top}$ is AJ888903.

Micrographs of cells of strain $J A 2^{\top}$ and figures showing whole-cell absorption and FT-IR spectra and a graph showing growth of and utilization of benzoate by strain $\mathrm{JA} 2^{\top}$ are available as supplementary material in IJSEM Online. palustris at the expense of benzoate. The discovery of benzoate utilization by Rhodospirillum fulvum (Pfennig et al., 1965) [renamed as Phaeospirillum fulvum (Imhoff et al., 1998)] led to the investigation of aromatic hydrocarbon degrading capability among other purple non-sulfur bacteria. Rhodopseudomonas palustris (Dutton \& Evans, 1967; Harwood \& Gibson, 1988), Phaeospirillum fulvum (Pfennig et al., 1965), Rhodopseudomonas acidophila (Yamanaka et al., 1983) [renamed as Rhodoblastus acidophilus (Imhoff, 2001)], Rhodomicrobium vannielii (Wright \& Madigan, 1991), Rhodobacter capsulatus (Blasco \& Castillo, 1992; Madigan et al., 2001), Rhodobacter sphaeroides (Rajasekhar et al., 2000), Blastochloris sulfoviridis (Zengler et al., 1999) and the bacteriochlorophyll-containing aerobic phototrophic bacterium Porphyrobacter sanguineus (Hiraishi et al., 2002) are phototrophic alphaproteobacteria that are capable of aromatic hydrocarbon metabolism. Phototrophic betaproteobacteria that utilize benzoate include Rhodocyclus purpureus (Pfennig, 1978) and Rhodoferax ferrireducens (Finneran et al., 
2003). Although Rhodocyclus gelatinosus [now Rubrivivax gelatinosus (Willems et al., 1991; Imhoff, 1995)] utilizes phloroglucinol for growth and photobiotransforms some other aromatic compounds (Sasikala \& Ramana, 1998), to date it is not known whether it can utilize benzoate as a carbon source or electron donor (Whittle et al., 1976). In this paper a new isolate $\left(\right.$ strain $\mathrm{JA} 2^{\mathrm{T}}$ ) is described, which was obtained through phototrophic enrichments on benzoate. Strain $\mathrm{JA} 2^{\mathrm{T}}$ clusters with members of the genus Rubrivivax of the Betaproteobacteria and metabolizes a wide range of aromatic hydrocarbons. Based on phenotypic characteristics and molecular studies, strain $\mathrm{JA}^{\mathrm{T}}{ }^{\mathrm{P}}$ represents a novel species of the genus Rubrivivax, for which the name of Rubrivivax benzoatilyticus sp. nov. is proposed.

Strain JA2 ${ }^{\mathrm{T}}$ was isolated from the rhizosphere of a flooded paddy field near Eluru, Andhra Pradesh, India. For isolation and cultivation of the isolate, Pfennig's mineral salts medium (Biebl \& Pfennig, 1981) supplemented with benzoate $(3 \mathrm{mM})$ as a carbon source and ammonium chloride $(0 \cdot 12 \%)$ as a nitrogen source was used, with incubation under light $(2400 \mathrm{~lx})$ at $30 \pm 2{ }^{\circ} \mathrm{C}$. Purification of the isolate was achieved by repeated streaking on agar slants that were sealed with suba seals and flushed with argon and incubated phototrophically $(2400 \mathrm{~lx})$ at $30 \pm 2{ }^{\circ} \mathrm{C}$. For comparative analysis, Rubrivivax gelatinosus ATCC $17011^{\mathrm{T}}$ was used under identical culture conditions. No distinct variation was observed in the colony morphologies of strain $\mathrm{JA} 2^{\mathrm{T}}$ and Rubrivivax gelatinosus ATCC $17011^{\mathrm{T}}$. Colonies of strain $\mathrm{JA}^{\mathrm{T}}$ grown photoheterotrophically were round, convex, smooth and dark-orange-brown in colour and surrounded by a thin opaque margin. Microscopical observations, such as cell shape, size, cell division and flagella, were performed using a phase-contrast microscope (Olympus-B201) and the internal membrane structures were viewed with a transmission electron microscope after the cells were processed as described by Hanada et al. (2002). Polyhydroxyalkanoates of a culture of strain $\mathrm{JA} 2^{\mathrm{T}}$ grown for $48 \mathrm{~h}$ on Pfennig's medium supplemented with $0.3 \%(\mathrm{w} / \mathrm{v})$ pyruvate were stained with Sudan black B (2\% in ethanol) (Smibert \& Krieg, 1981) or Nile blue (Ostle \& Holt, 1982).

Substrate utilization of carbon sources/electron donors was done in Pfennig's mineral salts medium by replacing benzoate with the test aliphatic substrate at a final concentration of $0.3 \%(\mathrm{w} / \mathrm{v})$, in a completely filled screwcap test-tube $(10 \times 100 \mathrm{~mm})$. For utilization of aromatic hydrocarbons as carbon sources/electron donors, the test substrates were used at a concentration of $3 \mathrm{mM}$, with sodium bicarbonate $(0 \cdot 1 \%, \mathrm{w} / \mathrm{v})$ in the medium. A culture grown in the absence of any added carbon source was used as the inoculum. Aromatic hydrocarbons such as cyclohexanol, cyclohexanone, catechol and resorcinol were added after membrane filtration to the autoclaved basal medium containing the nitrogen source. Filter-sterilized bicarbonate was added to the medium after autoclaving and the $\mathrm{pH}$ of the medium was adjusted with sterile $1 \mathrm{M} \mathrm{NaOH}$ or $1 \mathrm{M}$ $\mathrm{HCl}$ to $\mathrm{pH} 6 \cdot 8$. Nitrogen source utilization was tested by replacing ammonium chloride with various nitrogen sources $(0 \cdot 12 \%, \mathrm{w} / \mathrm{v})$. Diazotrophy was tested by growing the cells under a $\mathrm{N}_{2}$ atmosphere and also by using assays for acetylene reduction activity (Sasikala et al., 1990). Dry weight was determined from an $\mathrm{OD}_{660}$ versus dry weight graph, ranging from $0 \cdot 1$ to $1 \cdot 0 \mathrm{OD}_{660}$ prepared for strain $\mathrm{JA}^{\mathrm{T}}$ ( $\mathrm{OD}_{660}$ of $0 \cdot 1$ was equal to $0 \cdot 3 \mathrm{mg}$ dry weight per $\mathrm{ml}$ ). In vivo absorption spectra of cells collected from photoheterotrophic (malate; $0.3 \%, w / v$ ) cultures grown for $30 \mathrm{~h}$ were measured with a Spectronic Genesys 2 spectrophotometer in sucrose solution (Trüper \& Pfennig, 1981). Absorption spectra were also recorded from pigments extracted with acetone, after elution of the cell suspension with acetone through a $10 \times 200 \mathrm{~mm}$ column packed with aluminium oxide. Whole cellular components (fatty acids, intracellular and membrane proteins, polysaccharides, photosynthetic pigments and nucleic acids) of strain $\mathrm{JA} 2^{\mathrm{T}}$ were distinguished from Rubrivivax gelatinosus ATCC $17011^{\mathrm{T}}$ based on information obtained from fouriertransform infrared (FT-IR) spectroscopy. For FT-IR spectroscopy, $2-3 \mathrm{ml}$ exponentially grown culture was lyophilized and processed with $\mathrm{KBr}$ to make a pellet. Spectral characteristics were recorded in the transmission mode between wave numbers 4000 and $400 \mathrm{~cm}^{-1}$ at a resolution of $4 \mathrm{~cm}^{-1}$ and $20 \mathrm{kHz}$ scan speed in a Perkin Elmer FT-IR spectrophotometer (model 128).

Genomic DNA was extracted and purified according to the method of Marmur (1961) and the G+C content of the DNA was determined by HPLC (Mesbah et al., 1989). Cell material for $16 \mathrm{~S}$ rRNA gene sequencing was taken from 1-2 ml culture. PCR and 16S rRNA gene sequencing were performed as described previously (Shivaji et al., 2000). Sequences were aligned using the CLUSTAL $\mathrm{W}$ program (Thompson et al., 1994). The distance matrix was calculated on the basis of the algorithm according to Jukes \& Cantor (1969) with the DNADIST program within the PHYLIP package (Felsenstein, 1989). Maximum-likelihood phylogenetic trees were established using the DNAML module of the PHYLIP 3.6 program package. Bootstrap analysis was performed. DNA-DNA hybridization analysis was performed at the DSMZ (Germany).

Uprooted paddy at booting stage together with the soil was collected in a polyethylene bag and the rhizosphere soil was used after 3 days for phototrophic enrichment on benzoate. Six colonies obtained during purification were designated strains JA2 ${ }^{\mathrm{T}}$, JA4, JA5, JA6, JA7 and JA8. Colony morphologies of strains JA2 ${ }^{\mathrm{T}}$, JA4 and JA6 were identical: colonies were round, dark-orange-brown in colour with a thin opaque margin and grew on benzoate as a sole source of carbon/electron donor. Strain $\mathrm{JA}^{\mathrm{T}}$ was characterized further using a polyphasic approach.

Cells of strain $\mathrm{JA}^{\mathrm{T}}$ stained Gram-negative. They were rodshaped (see Supplementary Fig. S1 in IJSEM Online), $0 \cdot 7-1 \cdot 0 \mu \mathrm{m}$ in width and $2 \cdot 0-6 \cdot 0 \mu \mathrm{m}$ in length, motile by a single polar flagellum and formed a rosette-like arrangement. Electron micrographs of ultrathin sections of the cells 
revealed the absence of internal membrane structures in strain JA2 ${ }^{\mathrm{T}}$ (see Supplementary Fig. S2 in IJSEM Online). Stationary-phase cells of strain $\mathrm{JA} 2^{\mathrm{T}}$ contained refractive granules. Sudan black and Nile blue staining indicated the presence of polyhydroxyalkanoates. On average, the cells contained 15-30 polyhydroxyalkanoate granules per cell, as observed in ultrathin sections (Fig. 1). In addition, growth of the granules at various stages could be observed (using transmission electron microscopy) and, sometimes, almost the whole cell was filled with a single large granule. Eventually, the granules even burst open the cell and were released as small ovoid granules (Fig. 1). The polyhydroxyalkanoate content of the cells reached up to $80-85 \%$ of the total cell dry mass. The photosynthetically grown cell suspensions were orange-brown in colour. Whole-cell absorption spectra of strain $\mathrm{JA}^{\mathrm{T}}$ had absorption maxima at $378,488,520,590,802$ and $884 \mathrm{~nm}$, confirming the presence of bacteriochlorophyll $a$ (BChl $a$ ) (Supplementary Fig. S3 in IJSEM Online) and most probably the carotenoids spirilloxanthin and sphaeroidene.

Strain $\mathrm{JA} 2^{\mathrm{T}}$ grew photolithoautotrophically [anaerobically in the light (2400 lx), with $\mathrm{H}_{2}(20 \%$, v/v)/thiosulfate $(0 \cdot 1 \%$, $\mathrm{w} / \mathrm{v})$ and $\left.\mathrm{NaHCO}_{3}(0 \cdot 1 \%, \mathrm{w} / \mathrm{v})\right]$, photo-organoheterotrophically [anaerobically in the light $(2400 \mathrm{~lx})$ with malate $(0 \cdot 3 \%, \mathrm{w} / \mathrm{v})$ ] and chemo-organoheterotrophically [microaerobically in the dark with malate $(0.3 \%$, w/v)]. Fermentative growth [anaerobically in the dark with glucose/fructose $(0.3 \%, \mathrm{w} / \mathrm{v})]$ and chemolithoautotrophy [microaerobically in the dark with thiosulfate $(0 \cdot 1 \%$, w/v) and $\left.\mathrm{NaHCO}_{3}(0 \cdot 1 \% \mathrm{w} / \mathrm{v})\right]$ could not be demonstrated. The substrates that were utilized as carbon sources and electron donors under photo-organoheterotrophic conditions are given in the species description.

Ammonium chloride and molecular nitrogen were the nitrogen sources utilized by strain $\mathrm{JA} 2^{\mathrm{T}}$; urea, nitrate or nitrite did not support growth. $\mathrm{NaCl}$ was not obligatory for growth of strain $\mathrm{JA}^{\mathrm{T}}$, but up to $5 \%(\mathrm{v} / \mathrm{v})$ was tolerated. In addition, the strain did not require any growth factors

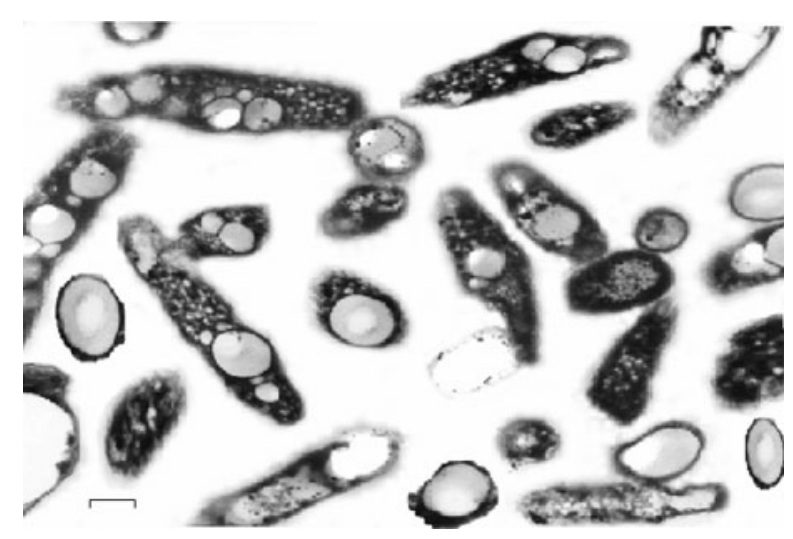

Fig. 1. Electron micrograph of ultrathin section of strain $J A 2^{\top}$ showing polyhydroxyalkanoate granules ( $\times 16240)$. Bar, $1 \mu \mathrm{m}$. (vitamins) and there was no enhancement in the biomass yield in their presence. Production of indole from tryptone was not observed; however, replacement of tryptone with tryptophan resulted in indole production. Gelatin liquefaction was observed. Using FT-IR spectroscopic data (Supplementary Fig. S4 in IJSEM Online), strain JA2 ${ }^{\mathrm{T}}$ showed visible spectral differences from Rubrivivax gelatinosus ATCC $17011^{\mathrm{T}}$, indicating variations in the composition of aromatic compounds (at $980 \mathrm{~cm}^{-1}$ ), polysaccharides $\left(1300-1100 \mathrm{~cm}^{-1}\right)$ and esters $\left(1726 \mathrm{~cm}^{-1}\right)$.

Aromatic hydrocarbons that supported photo-organoheterotrophic growth of strain $\mathrm{JA}_{2}{ }^{\mathrm{T}}$ included benzoate, 2-aminobenzoate (anthranilate), 4-aminobenzoate, 4-hydroxybenzoate, 2-carboxybenzoate (phthalate), phenylalanine, trans-cinnamate, benzamide, salicylate (2-hydroxybenzoate), cyclohexanone, cyclohexanol and cyclohexane-2-carboxylate (Table 1). Growth and simultaneous utilization of benzoate

Table 1. Growth and biomass yield of strain $\mathrm{JA} 2^{\top}$ on various aromatic hydrocarbons as carbon source/electron donors

Values shown are means of experiments performed in duplicate after 7 days of light $(2400 \mathrm{~lx})$ anaerobic incubation at $30 \pm 2{ }^{\circ} \mathrm{C}$. Phototrophic benzoate-grown cultures were used as the initial inoculum $(5 \%, \mathrm{v} / \mathrm{v})$. The compounds were utilized at a concentration of $3 \mathrm{mM}$, in the presence of $\mathrm{HCO}_{3}^{-}\left(0 \cdot 1 \%\right.$, w/v). $\mathrm{OD}_{660}$ values:,$+++>0 \cdot 50 ;++, 0 \cdot 3-0 \cdot 49 ;+, 0 \cdot 21-0 \cdot 29 ;$ GI, $<0 \cdot 2$ (growth inhibition). NA, Not applicable.

\begin{tabular}{|lc|}
\hline Carbon source/electron donor & Growth \\
\hline Benzoate & +++ \\
2-Aminobenzoate (anthranilate) & ++ \\
4-Aminobenzoate & + \\
Aniline & GI \\
Resorcinol & GI \\
4-Chlorobenzoate & GI \\
4-Hydroxybenzoate & +++ \\
2-Hydroxybenzoate (salicylate) & ++ \\
Phthalate & ++ \\
Diphenylamine & GI \\
Phenylalanine & +++ \\
Nitrobenzene & GI \\
4-Hydroxydiphenyl & GI \\
trans-Cinnamate & ++ \\
Benzamide & ++ \\
Sulfanilate & +++ \\
2,4-Dinitrophenol & GI \\
Phenol & GI \\
Pyrocatechol & GI \\
Cyclohexane* & GI \\
Cyclohexanone & ++ \\
Cyclohexanol & ++ \\
Cyclohexane-2-carboxylate & +++ \\
Control (without aromatic compound) & $\mathrm{NA}$ \\
\hline
\end{tabular}

${ }^{*}$ Tested at concentrations of $0.5,1.0$ and $3.0 \mathrm{mM}$. 
is shown in Supplementary Fig. S5 in IJSEM Online. The doubling time of strain $\mathrm{JA}^{\mathrm{T}}$ was about $35 \mathrm{~h}$ on benzoate, compared with $8 \mathrm{~h}$ on malate.

The $\mathrm{G}+\mathrm{C}$ content of strain $\mathrm{JA}^{\mathrm{T}}{ }^{\mathrm{T}}$ was $74.9 \mathrm{~mol} \%$ (by HPLC). The $16 \mathrm{~S}$ rRNA gene sequence of strain $\mathrm{JA}^{\mathrm{T}}$ formed a cluster with members of the genus Rubrivivax and showed $99 \%$ sequence similarity with Rubrivivax gelatinosus DSM $1709^{\mathrm{T}}$ ( = ATCC $17011^{\mathrm{T}}$ ). However, DNA-DNA hybridization of strain JA2 $2^{\mathrm{T}}$ with Rubrivivax gelatinosus ATCC $17011^{\mathrm{T}}$ revealed a relatedness value of only $54 \cdot 8 \%$.

The genus Rhodocyclus with three species, Rhodocyclus purpureus, Rhodocyclus tenuis and Rhodocyclus gelatinosus, was described in the first edition of Bergey's Manual of Systematic Bacteriology (Imhoff \& Trüper, 1989). Based on 16S rRNA gene sequence analysis, even though all three species were grouped in the class Betaproteobacteria (Stackebrandt et al., 1988), significant phylogenetic differences separated Rhodocyclus gelatinosus from the other two species, thus necessitating the description of a new genus, Rubrivivax, with Rubrivivax gelatinosus as the type species (Willems et al., 1991). Rubrivivax gelatinosus is phylogenetically related to members (genera Tepidimonas, Aquabacterium, Ideonella,
Leptothrix, Roseateles, Sphaerotilus, Thiomonas, Xylophilus) of the family incertae sedis (Cole et al., 2003) [Rubrivivax gelatinosus was previously included in the family Comamonadaceae (Willems et al., 1991; Wen et al., 1999)], separating it from the genera Rhodoferax and Rhodocyclus. The genus Rhodoferax, a later addition to the family Comamonadaceae, to date includes two phototrophic species, Rhodoferax fermentans (Hiraishi et al., 1991) and Rhodoferax antarcticus (Madigan et al., 2000), and the non-pigmented Rhodoferax ferrireducens (Finneran et al., 2003). Pairwise sequence comparisons and distance matrix tree analysis showed that the genera Rhodoferax, Rubrivivax and Rhodocyclus formed three separate lineages within the Betaproteobacteria (Hiraishi, 1994). Based on the 16S rRNA gene sequence analysis, strain $\mathrm{JA}^{\mathrm{T}}$ clustered closely with members of the family incertae sedis within the genus Rubrivivax (Fig. 2). However, the morphological, physiological and biochemical traits (Table 2) and DNADNA hybridization studies significantly differentiated this strain from the only reported species of Rubrivivax, Rubrivivax gelatinosus, and therefore strain $\mathrm{JA}^{\mathrm{T}}$ is described here as a novel species, Rubrivivax benzoatilyticus. FT-IR spectroscopic data, which are considered to be a connecting link between genomic and phenotypic approaches (Amiel

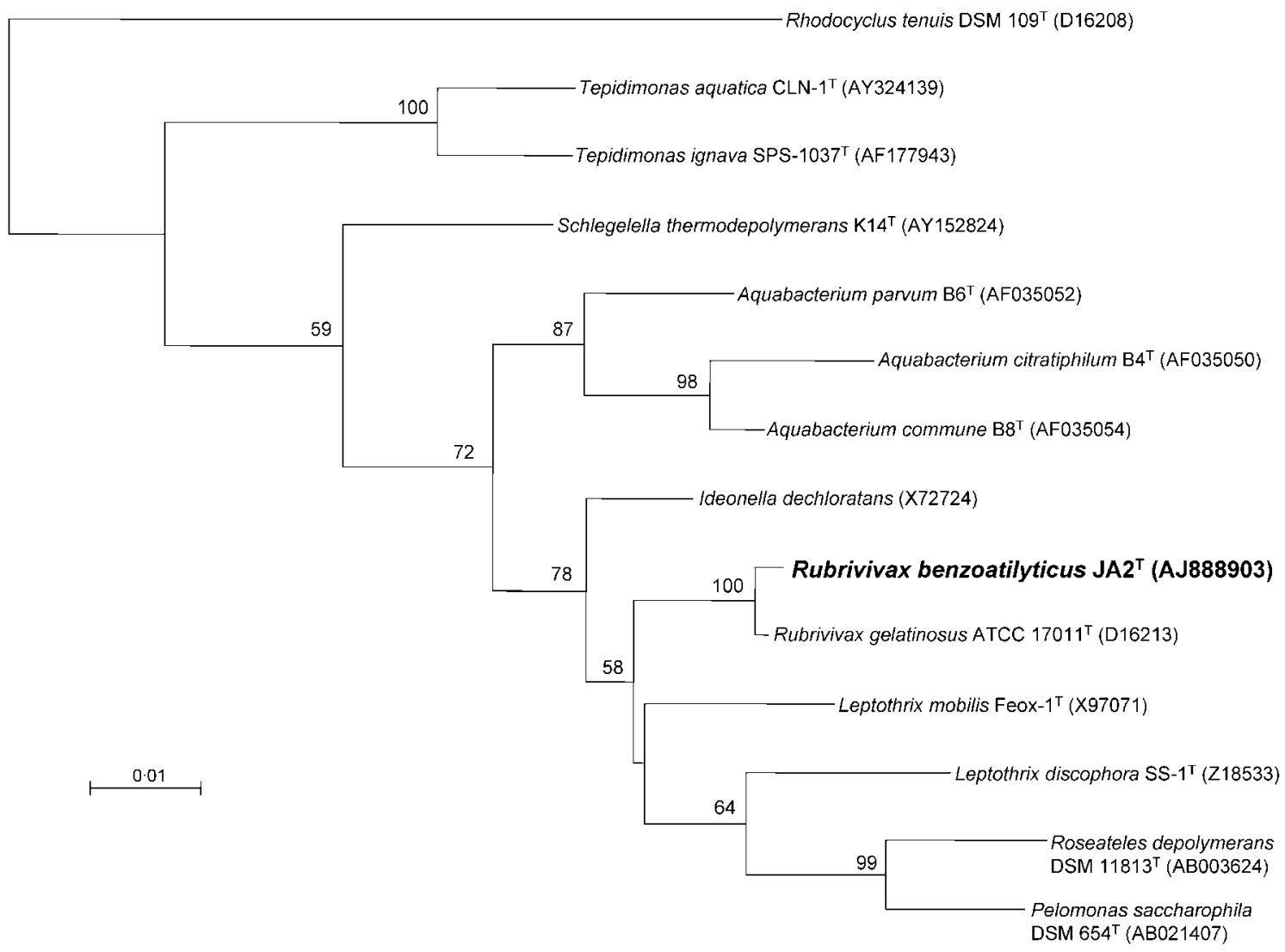

Fig. 2. Dendrogram depicting the phylogenetic relationships of strain $J A 2^{\top}$ within the family incertae sedis of the Betaproteobacteria based on 16S rRNA gene sequence analysis. Numbers at nodes are confidence values of bootstrap analyses with 100 resamplings. Bar, 1 nucleotide substitution per 100 nucleotides. 
Table 2. Characteristics that differentiate strain $J A 2^{\top}$ from related freshwater purple betaproteobacteria

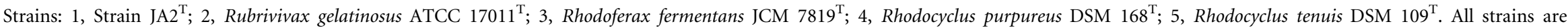
chemo-organotrophic and utilize acetate, butyrate, succinate and ethanol. +, Positive/substrate utilized; -, negative/not utilized; NT, not tested.

\begin{tabular}{|c|c|c|c|c|c|}
\hline Characteristic & 1 & $2^{*}$ & $3^{*}$ & $4^{*}$ & $5^{\star}$ \\
\hline Cell shape & Rod & Rod & Curved rod & Half-circle & Spiral \\
\hline \multicolumn{6}{|l|}{ Cell size: } \\
\hline Width $(\mu \mathrm{m})$ & $0 \cdot 7-1 \cdot 0$ & $0 \cdot 4-0 \cdot 5$ & $0 \cdot 6-0 \cdot 9$ & $0 \cdot 6-0 \cdot 7$ & $0 \cdot 3-0 \cdot 5$ \\
\hline Length $(\mu \mathrm{m})$ & $2 \cdot 0-6 \cdot 0$ & $1 \cdot 0-3 \cdot 0$ & $1 \cdot 5-3 \cdot 0$ & $2 \cdot 0-3 \cdot 0$ & $1 \cdot 5-6 \cdot 0$ \\
\hline Flagella & Single polar & Single polar & Single polar & Non-motile & Single polar \\
\hline $\mathrm{NaCl}$ requirement & - & - & + & - & - \\
\hline Optimum $\mathrm{NaCl}$ concentration & NT & NT & $<1 \%$ & NT & NT \\
\hline Vitamin requirement & - & Biotin and thiamine & Biotin and thiamine & $\mathrm{B}_{12}$ and $p-\mathrm{ABA} \dagger$ & - \\
\hline Fermentation & - & - & + & - & - \\
\hline Colour of culture suspension & Orange-brown & Pale-peach/dirty yellowish-brown & Peach-brown & Purple-violet & Brownish-red or purple-violet \\
\hline Carotenoids & Sphaeroidene series & Sphaeroidene series & Sphaeroidene series & Rhodopinal series & Rhodopinal series \\
\hline Intracytoplasmic membrane & - & Tubes & - & Tubes & Tubes \\
\hline Gelatin liquefaction & + & + & - & - & - \\
\hline DNA G $+C$ content $(\mathrm{mol} \%)$ & $74 \cdot 9$ & $70 \cdot 5-72 \cdot 4$ & $59 \cdot 8-60 \cdot 3$ & $64-65$ & $64-65$ \\
\hline \multicolumn{6}{|l|}{ Utilization of organic substrates: } \\
\hline Formate & + & + & - & - & - \\
\hline Propionate & + & + & - & - & + \\
\hline Valerate & - & + & NT & - & + \\
\hline Caproate & + & NT & - & + & + \\
\hline Pyruvate & + & + & + & - & + \\
\hline Lactate & - & + & + & - & - \\
\hline Citrate & - & + & - & + & - \\
\hline Malate & + & + & + & - & + \\
\hline Fumarate & + & + & + & - & + \\
\hline Tartarate & + & + & NT & - & - \\
\hline Glutamate & + & + & + & - & - \\
\hline Glucose & + & + & + & - & - \\
\hline Fructose & + & + & + & - & - \\
\hline Mannitol & - & - & + & - & - \\
\hline Glycerol & + & - & - & - & - \\
\hline Methanol & - & + & - & - & - \\
\hline Benzoate & + & - & - & + & - \\
\hline
\end{tabular}

${ }^{*}$ Data from Willems et al., 1991, Hiraishi et al., 1991 and Pfennig \& Trüper 1989. 
et al., 2001), have shown differences between strain $\mathrm{JA}^{\mathrm{T}}$ and Rubrivivax gelatinosus ATCC $17011^{\mathrm{T}}$ in a few major cellular components, viz., aromatic compounds, polysaccharides and esters (see Supplementary Fig. S4 in IJSEM Online).

Curved cells commonly observed with Rubrivivax gelatinosus (Willems et al., 1991) were not observed with strain JA2 ${ }^{\mathrm{T}}$, the cells of which were always straight rods. One significant difference between strain $\mathrm{JA}^{\mathrm{T}}$ and the other Rubrivivax species is the absence of internal membrane structures, which form tubular intrusions in Rubrivivax gelatinosus (Willems et al., 1991). In terms of the lack of internal membrane structures, strain $\mathrm{JA} 2^{\mathrm{T}}$ more probably resembles Rhodoferax species (Hiraishi et al., 1991). Preliminary analysis of the carotenoid content of strain $\mathrm{JA} 2^{\mathrm{T}}$ indicated that it probably has both sphaeroidene and spirilloxanthin series of carotenoids, again similar to Rubrivivax gelatinosus. This is in contrast to Rhodobacter capsulatus and Rhodobacter sphaeroides, which only have carotenoids of the sphaeroidene series (Pinta et al., 2003; Harada et al., 2001; Steiger et al., 2000). The other major difference between strain $\mathrm{JA} 2^{\mathrm{T}}$ and many other phototrophic members of the Alphaproteobacteria and Betaproteobacteria is the lack of any vitamin requirement for growth, which is rather rare in this group (Imhoff, 1995). Rhodocyclus tenuis and Roseateles depolymerans (an aerobic BChl a-containing bacterium; Suyama et al., 1999) are the only other species of phototrophic Betaproteobacteria that do not have a requirement for vitamins.

Strain JA2 ${ }^{\mathrm{T}}$ produced large amounts (up to $85 \%$ of the cell dry weight) of polyhydroxyalkanoates. A similar yield of polyhydroxyalkanoate from Ralstonia (Alcaligenes) eutropha has been reported, with accumulation of up to $96 \%$ of the cellular dry weight (Pedrosalio et al., 1985). This is exploited commercially for biopolyester production (Sasikala \& Ramana, 1996).

Strain $\mathrm{JA} 2^{\mathrm{T}}$ did not produce indole directly from tryptone; however, indole production from tryptophan was observed. This suggests that strain $\mathrm{JA} 2^{\mathrm{T}}$ is unable to hydrolyse tryptone, in contrast to the extensive proteolytic capabilities of Rubrivivax gelatinosus (Tanskul et al., 2003). Therefore we recommend the use of tryptophan for the indole production (tryptophanase) test rather than tryptone. Production of indole from tryptophan, catalysed by the enzyme tryptophanase, is a common diagnostic marker for differentiating members of Enterobacteriaceae, including Escherichia coli, Proteus vulgaris, Providencia spp. and Morganella spp. (Sonnenwirth, 1980), which belong to the Gammaproteobacteria.

Anoxygenic phototrophic bacteria capable of photo-organotrophic utilization of aromatic hydrocarbons mainly belong to the Alphaproteobacteria and among the photosynthetic Betaproteobacteria, Rhodocyclus purpureus and strain $\mathrm{JA} 2^{\mathrm{T}}$ are capable of benzoate utilization. In addition, anaerobic aromatic hydrocarbon degradation among the Alphaproteobacteria is restricted to the photosynthetic members, whereas it is common among members of the Betaproteobacteria, including species of Thauera and Azoarcus (Heider \& Fuchs, 1997). Strain JA2 ${ }^{\mathrm{T}}$ degraded a variety of aromatic hydrocarbons (Table 1 ), adding to the aromatic hydrocarbon degrading diversity of phototrophic bacteria (Sasikala \& Ramana, 1998).

\section{Description of Rubrivivax benzoatilyticus sp. nov.}

Rubrivivax benzoatilyticus (ben.zo'at.i.ly'ti.cus. N.L. n. benzoas -atis benzoate; Gr. adj. lutikos able to loose, able to dissolve; N.L. adj. lyticus dissolving; N.L. masc. adj. benzoatilyticus dissolving benzoate, named after its utilization of benzoate).

Cells are rod-shaped, $0 \cdot 7-1 \cdot 0 \mu \mathrm{m}$ wide and $2 \cdot 0-6 \cdot 0 \mu \mathrm{m}$ long. Motile by means of a single polar flagellum. Colour of the cell suspension is orange-brown and cells multiply by binary fission. Colony morphology on agar slants is round, convex and smooth, with dark orange-brown colour surrounded by thin opaque margin. Internal membranes are absent. Intact cells have absorption maxima at 378, 488, 520, 590, 802 and $884 \mathrm{~nm}$. Photosynthetic pigments are BChl $a$ and probably carotenoids of the alternative spirilloxanthin series with both sphaeroidene and spirilloxanthin. Growth modes are photo- and chemo-organoheterotrophy and photolithoautotrophy. Organic substrates photometabolized include formate, acetate, propionate, butyrate, valerate, succinate, malate, fumarate, oxaloacetate, 2-oxoglutarate, pyruvate, glucose, fructose, tartarate, glutamate, glycerol, ethanol and benzoate. Does not metabolize lactate, citrate, mannitol, methanol or sorbitol. Inorganic electronic donors such as molecular hydrogen and thiosulfate support growth. $\mathrm{NaCl}$ and vitamins are not required for growth. The DNA $\mathrm{G}+\mathrm{C}$ content of the type strain is $74 \cdot 9 \mathrm{~mol} \%$ (HPLC).

The type strain is $\mathrm{JA}^{\mathrm{T}} \quad\left(=\mathrm{ATCC} \quad \mathrm{BAA}-35^{\mathrm{T}}=\mathrm{JCM}\right.$ $13220^{\mathrm{T}}=$ MTCC $7087^{\mathrm{T}}$ ). Habitat is rhizosphere of flooded paddy.

\section{Acknowledgements}

Financial assistance received from the Department of Ocean Development, the Department of Science and Technology, the Department of Biotechnology, Government of India are acknowledged. K. A., acknowledges the CSIR, Government of India, for the award of research associateship, and P.A. and T.N.R.S. acknowledge the award of senior research fellowships. DST and DAAD are acknowledged for funding exchange of visits.

\section{References}

Amiel, C., Mariey, L., Denis, C., Pichon, P. \& Travert, J. (2001). FTIR spectroscopy and taxonomic purpose: contribution to the classification of lactic acid bacteria. Lait 81, 249-255.

Biebl, H. \& Pfennig, N. (1981). Isolation of members of the family Rhodospirillaceae. In The Prokaryotes, pp. 167-273. Edited by M. P. 
Starr, H. Stolp, H. G. Trüper, A. Balows \& H. G. Schlegel. New York: Springer.

Blasco, R. \& Castillo, F. (1992). Light-dependent degradation of nitrophenols by the phototrophic bacterium Rhodobacter capsulatus E1F1. Appl Environ Microbiol 58, 690-695.

Cole, J. R., Chai, B., Marsh, T. L. \& 8 other authors (2003). The Ribosomal Database Project (RDP-II): previewing a new autoaligner that allows regular updates and the new prokaryotic taxonomy. Nucleic Acids Res 31, 442-443. RDP-II Hierarchy Browser, http://rdp. cme.msu.edu/hierarchy/hierarchy_browser.jsp?qvector $=8 \& d e p t h=0 \&$ openNode $=0 \&$ seqid $=\&$ currentRoot $=1616 \&$ searchStr $=\& e n d D a t a V a l u e$ $=\&$ showOpt

Dutton, P. L. \& Evans, W. C. (1967). Dissimilation of aromatic substrates by Rhodopseudomonas palustris. Biochem J 104, 30-31.

Felsenstein, J. (1989). PHYLIP - Phylogeny inference package (version 3.2). Cladistics 5, 164-166.

Finneran, K. T., Johnsen, C. V. \& Lovley, D. R. (2003). Rhodoferax ferrireducens sp. nov., a psychrotolerant, facultatively anaerobic bacterium that oxidizes acetate with the reduction of $\mathrm{Fe}(\mathrm{III})$. Int J Syst Evol Microbiol 53, 669-673.

Frank, J. \& Gaffron, H. (1941). Photosynthesis. Facts and interpretations. Adv Enzymol Relat Subj Biochem 1, 199-202.

Hanada, S., Takaichi, S., Matsuura, K. \& Nakamura, K. (2002). Roseiflexus castenholzii gen. nov., sp. nov., a thermophilic, filamentous, photosynthetic bacterium that lacks chlorosomes. Int J Syst Evol Microbiol 52, 187-193.

Harada, J., Nagashima, K. V., Takaichi, S., Misawa, N., Matsuura, K. \& Shimada, K. (2001). Phytoene desaturase, CrtI, of the purple photosynthetic bacterium, Rubrivivax gelatinosus, produces both neurosporene and lycopene. Plant Cell Physiol 42, 1112-1118.

Harwood, C. S. \& Gibson, J. (1988). Anaerobic and aerobic metabolism of diverse aromatic compounds by the photosynthetic bacterium Rhodopseudomonas palustris. Appl Environ Microbiol 54, 712-717.

Heider, J. \& Fuchs, G. (1997). Microbial anaerobic aromatic metabolism. Anaerobe 3, 1-22.

Hiraishi, A. (1994). Phylogenetic affiliations of Rhodoferax fermentans and related species of phototrophic bacteria as determined by automated 16S rDNA sequencing. Curr Microbiol 28, 25-29.

Hiraishi, A., Hoshino, Y. \& Satoh, T. (1991). Rhodoferax fermentans gen. nov., sp. nov., a phototrophic purple non sulfur bacterium previously referred to as the "Rhodocyclus gelatinosus-like" group. Arch Microbiol 155, 330-336.

Hiraishi, A., Yonemitsu, Y., Matsushita, M., Shin, Y. K., Kuraishi, H. \& Kawahara, K. (2002). Characterization of Porphyrobacter sanguineus sp. nov., an aerobic bacteriochlorophyll-containing bacterium capable of degrading biphenyl and dibenzofuran. Arch Microbiol 178, 45-52.

Imhoff, J. F. (1995). Taxonomy and physiology of phototrophic purple bacteria and green sulfur bacteria. In Anoxygenic Photosynthetic Bacteria, pp. 1-15. Edited by R. E. Blankenship, M. T. Madigan \& C. E. Bauer. Dordrecht: Kluwer.

Imhoff, J. F. (2001). Transfer of Rhodopseudomonas acidophila to the new genus Rhodoblastus as Rhodoblastus acidophilus gen. nov., comb. nov. Int J Syst Evol Microbiol 51, 1863-1866.

Imhoff, J. F. \& Trüper, H. G. (1989). Genus Rhodocyclus Pfennig 1978, $285^{\mathrm{AL}}$. In Bergey's Manual of Systematic Bacteriology, vol. 3, pp. 1678-1682. Edited by J. T. Staley, M. P. Bryant, N. Pfennig \& J. G. Holt. Baltimore: Williams \& Wilkins.

Imhoff, J., Petri, R. \& Süling, J. (1998). Reclassification of species of the spiral-shaped phototrophic purple non-sulfur bacteria of the $\alpha$ Proteobacteria: description of the new genera Phaeospirillum gen. nov., Rhodovibrio gen. nov., Rhodothalassium gen. nov. and Roseospira gen. nov. as well as transfer of Rhodospirillum fulvum to Phaeospirillum fulvum comb. nov., of Rhodospirillum molischianum to Phaeospirillum molischianum comb. nov., of Rhodospirillum salinarum to Rhodovibrio salinarum comb. nov., of Rhodospirillum sodomense to Rhodovibrio sodomensis comb. nov., of Rhodospirillum salexigens to Rhodothalassium salexigens comb. nov. and of Rhodospirillum mediosalinum to Roseospira mediosalina comb. nov. Int J Syst Bacteriol 48, 793-798.

Jukes, T. H. \& Cantor, C. R. (1969). Evolution of protein molecules. In Mammalian Protein Metabolism, pp. 21-132. Edited by $\mathrm{H}$. N. Munro. New York: Academic Press.

Madigan, M. T., Jung, D. O., Woese, C. R. \& Achenbach, L. A. (2000). Rhodoferax antarcticus sp. nov., a moderately psychrophilic purple nonsulfur bacterium isolated from an antarctic microbial mat. Arch Microbiol 173, 269-277.

Madigan, M. T., Jung, D. O. \& Resnick, S. M. (2001). Growth of the purple bacterium Rhodobacter capsulatus on the aromatic compound hippurate. Arch Microbiol 175, 462-465.

Marmur, J. (1961). A procedure for the isolation of deoxyribonucleic acid from microorganisms. J Mol Biol 3, 208-218.

Mesbah, M., Premachandran, U. \& Whitman, W. B. (1989). Precise measurement of the $\mathrm{G}+\mathrm{C}$ content of deoxyribonucleic acid by high-performance liquid chromatography. Int J Syst Bacteriol 39, 159-167.

Ostle, A. G. \& Holt, J. G. (1982). Nile blue A as a fluorescent stain for poly- $\beta$-hydroxybutyrate. Appl Environ Microbiol 44, 238-241.

Pedrosalio, C., Mas, J. \& Guerrero, R. (1985). The influence of poly$\beta$-hydroxy butyrate accumulation on cell-volume and buoyant density in Alcaligenes eutrophus. Arch Microbiol 143, 178-184.

Pfennig, N. (1978). Rhodocyclus purpureus gen. nov. and sp. nov., a ring-shaped, vitamin $B_{12}$-requiring member of the family Rhodospirillaceae. Int J Syst Bacteriol 28, 283-288.

Pfennig, N. \& Trüper, H. G. (1989). Family I. Chromatiaceae Bavendamm 1924, 125, ${ }^{\text {AL }}$ emended description Imhoff 1984, 339. In Bergey's Manual of Systematic Bacteriology, vol. 3, pp. 1637-1653. Edited by J. T. Staley, M. P. Bryant, N. Pfennig \& J. G. Holt. Baltimore: Williams \& Wilkins.

Pfennig, N., Eimhjellen, K. E. \& Liaaen-Jensen, S. (1965). A new isolate of the Rhodospirillum fulvum group and its photosynthetic pigments. Arch Mikrobiol 51, 258-266.

Pinta, V., Ouchane, S., Picaud, M., Takaichi, S., Astier, C. \& ReissHusson, F. (2003). Characterization of unusual hydroxy- and ketocarotenoids in Rubrivivax gelatinosus: involvement of enzyme CrtF or CrtA. Arch Microbiol 179, 354-362.

Rajasekhar, N., Sasikala, Ch. \& Ramana, Ch. V. (2000). Toxicity of $\mathrm{N}$-containing heterocyclic aromatic compounds and their utilization for growth by a few purple non-sulfur bacteria. Bull Environ Contam Toxicol 65, 375-382.

Sasikala, K., Ramana, Ch. V., Raghuveer Rao, P. \& Subrahmanyam, M. (1990). Photoproduction of hydrogen, nitrogenase and hydrogenase activities of free and immobilized whole cells of Rhodobacter sphaeroides O.U.001. FEMS Microbiol Lett 72, 23-28.

Sasikala, Ch. \& Ramana, Ch. V. (1996). Biodegradable polyesters. Adv Applied Microbiol 42, 97-218.

Sasikala, Ch. \& Ramana, Ch. V. (1998). Biodegradation and metabolism of unusual carbon compounds by anoxygenic phototrophic bacteria. Adv Microbial Physiol 39, 339-377.

Scher, S. \& Allen, N. B. (1960). Photochemical oxidation of aromatic acids by Rhodopseudomonas. Bacteriol Proc 60, 67-71.

Scher, S. \& Proctor, M. H. (1960). Studies with photosynthetic bacteria: anaerobic oxidation of aromatic compounds. In 
Comparative Biochemistry of Photoreactive Systems, pp. 387-392. Edited by M. B. Allen. New York: Academic Press.

Shivaji, S., Bhanu, N. V. \& Aggarwal, R. K. (2000). Identification of Yersinia pestis as the causative organism of plague in India as determined by $16 \mathrm{~S}$ rDNA sequencing and RAPD-based genomic fingerprinting. FEMS Microbiol Lett 189, 247-252.

Smibert, R. M. \& Krieg, N. R. (1981). General characterization. In Manual of Methods for General Microbiology, pp. 409-443. Edited by R. G. E. Gerhardt, R. N. Costilow, E. W. Nester, W. A. Wood, N. R. Krieg \& G. B. Phillips. Washington, DC: American Society for Microbiology.

Sonnenwirth, A. C. (1980). The enteric bacteria and bacteroids. In Microbiology, 3rd edn, pp. 645-672. Edited by B. D. Davis, R. Dulbecco, H. N. Eisen \& H. S. Ginsberg. New York: Harper \& Row.

Stackebrandt, E., Murray, R. G. E. \& Trüper, H. G. (1988). Proteobacteria classis nov., a name for the phylogenetic taxon that includes the "purple bacteria and their relatives". Int J Syst Bacteriol 38, 321-325.

Steiger, S., Astier, C. \& Sandmann, G. (2000). Substrate specificity of the expressed carotenoid 3,4-desaturase from Rubrivivax gelatinosus reveals the detailed reaction sequence to spheroidene and spirilloxanthin. Biochem J 349, 635-640.

Suyama, T., Shigematsu, T., Takaichi, S., Nodasaka, Y., Fujikawa, S., Hosoya, H., Tokiwa, Y., Kanagawa, T. \& Hanada, S. (1999). Roseateles depolymerans gen. nov., sp. nov., a new bacteriochlorophyll $a$-containing obligate aerobe belonging to the $\beta$-subclass of the Proteobacteria. Int J Syst Bacteriol 49, 449-457.

Tanskul, S., Oda, K., Oyama, H., Noparatnaraporn, N., Tsunemi, M. \& Takada, K. (2003). Substrate specificity of alkaline serine proteinase isolated from photosynthetic bacterium, Rubrivivax gelatinosus KDDS1. Biochem Biophys Res Commun 309, 547-551.
Thompson, J. D., Higgins, D. G. \& Gibson, T. J. (1994). CLUSTAL W: improving the sensitivity of progressive multiple sequence alignment through sequence weighting, position-specific gap penalties and weight matrix choice. Nucleic Acids Res 22, 4673-4680.

Trüper, H. G. \& Pfennig, N. (1981). Characterization and identification of the anoxygenic phototrophic bacteria. In The Prokaryotes, pp. 299-312. Edited by M. P. Starr, H. Stolp, H. G. Trüper, A. Balows \& H. G. Schlegel. New York: Springer.

Wen, A., Fegan, M., Hayward, C., Chakraborty, S. \& Sly, L. I. (1999). Phylogenetic relationships among members of the Comamonadaceae, and description of Delftia acidovorans (den Dooren de Jong 1926 and Tamaoka et al. 1987) gen. nov., comb. nov. Int J Syst Bacteriol 49, 567-576.

Whittle, P. J., Lunt, D. O. \& Evans, W. C. (1976). Anaerobic photometabolism of aromatic compounds by Rhodopseudomonas sp. Biochem Soc Trans 4, 490-491.

Willems, A., Gillis, M. \& de Ley, J. (1991). Transfer of Rhodocyclus gelatinosus to Rubrivivax gelatinosus gen. nov., comb nov., and phylogenetic relationships with Leptothrix, Sphaerotilus natans, Pseudomonas saccharophila and Alcaligenes latus. Int $J$ Syst Bacteriol 41, 65-73.

Wright, G. E. \& Madigan, M. T. (1991). Photocatabolism of aromatic compounds by the phototrophic purple bacterium Rhodomicrobium vannielii. Appl Environ Microbiol 57, 2069-2073.

Yamanaka, K., Moriyama, M., Minoshima, R. \& Tsayuski, Y. (1983). Isolation and characterization of methanol-utilizing phototrophic bacterium Rhodopseudomonas acidophila M402 and its growth on vanillin derivatives. Agric Biol Chem 47, 1257-1267.

Zengler, K., Heider, J., Rosselló-Mora, R. \& Widdel, F. (1999). Phototrophic utilization of toluene under anoxic conditions by a new strain of Blastochloris sulfoviridis. Arch Microbiol 172, 204-212. 